\title{
A contribution to the understanding of phylogenetic relationships among species of the genus Octopus (Octopodidae: Cephalopoda)
}

\author{
MARÍA SOLEDAD ACOSTA-JOFRÉ ${ }^{1,3}$, RICARDO SAHADE $^{1,3}$, JÜRGEN LAUDIEN $^{4}$ \\ and MARINA B. CHIAPPERO ${ }^{2,3}$ \\ ${ }^{1}$ Cátedra de Ecología Marina, Facultad de Ciencias Exactas, Físicas y Naturales, \\ Universidad Nacional de Córdoba, Argentina. \\ ${ }^{2}$ Cátedra de Genética de Poblaciones y Evolución, Facultad de Ciencias Exactas, Físicas y Naturales, \\ Universidad Nacional de Córdoba, Argentina. E-mail: mchiappero@efn.unc.edu.ar \\ ${ }^{3}$ Consejo Nacional de Investigaciones Científicas y Técnicas (CONICET), Argentina. \\ ${ }^{4}$ Alfred Wegener Institute for Polar and Marine Research, Bremerhaven, Germany.
}

SUMMARY: Many species of the genus Octopus are important resources for fisheries worldwide. Its approximately 200 species show a strong similarity in structural morphology and a wide diversity in skin coloration and patterning, behaviour and life strategies that have hampered the study of phylogenetic relationships. We used a Bayesian approach to estimate as yet unknown phylogenetic relationships among $O$. tehuelchus from the southwestern Atlantic, new specimens of $O$. mimus (Chile and Peru) and other Octopus species, and used Bayes factors to test phylogenetic hypotheses. O. tehuelchus was more closely related to the genera Callistoctopus, Grimpella and Macroctopus than to Octopus, and therefore its generic placement may need a revision. $O$. vulgaris specimens from Costa Rica (Pacific Ocean) and $O$. oculifer grouped with $O$. mimus. Bayes factors showed positive evidence in favor of this grouping and therefore these individuals could have been misidentified, being in fact $O$. mimus. O. vulgaris specimens from the Costa Rican Caribbean were more related to $O$. mimus than to other $O$. vulgaris and could represent a cryptic species. The remaining $O$. vulgaris clustered with $O$. tetricus. Bayes factors found strong evidence against the monophyly of $O$. vulgaris as currently defined, giving statistical support to the monophyly of an $O$. vulgaris s. str. $+O$. tetricus group proposed previously by other authors.

Keywords: Octopus mimus, Octopus tehuelchus, phylogeny, cytochrome oxidase subunit III, Bayes factors.

RESUMEN: CONTRIBUCIÓN AL CONOCIMIENTO DE LAS RELACIONES FILOGENÉTICAS ENTRE ESPECIES DEL GÉNERO OCTOPUS (Octopodidae: Cephalopoda). - Numerosas especies del género Octopus constituyen un recurso importante para las pesquerías en todo el mundo. Sus aproximadamente 200 especies presentan a la vez una importante similitud en morfología y una amplia diversidad en el patrón y coloración de la piel, comportamiento y estrategias de vida, lo cual ha dificultado el estudio de las relaciones filogenéticas. En este trabajo estimamos las relaciones filogenéticas entre $O$. tehuelchus del Atlántico sudoccidental (cuyas relaciones con otras especies de la subfamilia son desconocidas), nuevos especímenes de $O$. mimus (Chile y Perú) y otras especies de Octopus, utilizando métodos de estimación bayesiana. Además utilizamos tests de factores de Bayes para comprobar hipótesis filogenéticas. O. tehuelchus estuvo más cercanamente relacionado a los géneros Callistoctopus, Grimpella y Macroctopus que a Octopus, y por lo tanto su ubicación genérica debería ser revisada. Los especímenes de $O$. vulgaris de Costa Rica (Océano Pacífico) y $O$. oculifer, se agruparon junto con $O$. mimus. Los factores de Bayes mostraron evidencia positiva a favor de este agrupamiento, por lo que estos ejemplares podrían representar ejemplares de O. mimus mal clasificados. Los especímenes de O. vulgaris del Mar Caribe de Costa Rica podrían constituir una especie críptica ya que estuvieron más cercanamente relacionados a $O$. mimus que a los restantes $O$. vulgaris. Estos últimos se agruparon con $O$. tetricus. Los factores de Bayes mostraron una fuerte evidencia a favor de este agrupamiento, dando soporte estadístico a la monofilia de $O$. vulgaris s. str. $+O$. tetricus propuesta previamente por otros autores.

Palabras clave: Octopus mimus, Octopus tehuelchus, filogenia, citocromo oxidasa subunidad III, factores de Bayes. 


\section{INTRODUCTION}

The genus Octopus (Lamarck 1798) (Cephalopoda: Octopodidae: Octopodinae) includes approximately 200 species, many of which are important resources for fisheries worldwide. The genus is found in shallow waters of all oceans except in the polar regions. It displays a wide diversity in skin coloration, behaviour and life strategies but a strong similarity in structural morphology; as a consequence, phylogenetic relationships, species limits and identification are difficult to establish (Robson 1929, Roper and Hochberg 1988, Hochberg et al. 1992, Voight 1994, and reviewed in Guzik et al. 2005). In the last few years, molecular techniques have been increasingly applied to increase the accuracy of phylogenetic relationships assessments. For example, Barriga Sosa et al. (1995) examined five Octopus species from the northern Pacific Ocean using the mitochondrial cytochrome oxidase III (COIII) gene. They confirmed the species-level status of $O$. bimaculoides and $O$. bimaculatus, two two-spotted octopuses that occur sympatrically. Carlini et al. (2001), using cytochrome oxidase I, and Guzik et al. (2005), using one nuclear (Elongation Factor-1 $\alpha$ ) and two mitochondrial (cytochrome oxidase III and cytochrome b) genes, estimated the phylogenetic relationships among several Octopus species; these authors found that Octopus is not a monophyletic genus, although it includes monophyletic groups. However, Norman and Hochberg (2005), in a revision of the species-level taxonomy of the family Octopodidae, reassigned several of the species considered as belonging to the genus Octopus to other genera such as Amphioctopus, Callistoctopus and Enteroctopus, while others were considered as "unplaced" and left for the moment in the genus Octopus until a major revision is undertaken.

There are also taxonomic problems regarding the species $O$. vulgaris, whose status as a true cosmopolitan species or as a species complex is uncertain (Guerra et al. 2010). Warnke et al. (2004) used COIII and 16rRNA genes to clarify the limits and distribution of the species $O$. vulgaris. They revealed that populations from the Mediterranean, the western and eastern Atlantic, Venezuela, Japan and Taiwan form a monophyletic clade, confirming the presence of the species in the north-western Pacific. O. mimus was more closely related to $O$. bimaculoides than to $O$. vulgaris. However, as they included few species and specimens in their analyses, monophyly could be an artifact of poor species sampling. Guerra et al. (2010), using COI and COIII genes, estimated phylogenetic relationships among a larger sample of species of the genus Octopus and included specimens of $O$. vulgaris from more geographic locations. They found that $O$. vulgaris from the southern Indian Ocean clustered with a high bootstrap percentage to those specimens of Warnke $(O$. vulgaris sensu stricto). However, this group clustered with $O$. tetricus from Australia; the remaining specimens of $O$. vulgaris (from the Caribbean Sea and Pacific Ocean) clustered together with $O$. mimus (from Iquique, Chile, and from the Pacific Ocean near Costa Rica), and $O$. oculifer from the Galapagos Islands, and were placed in the same major cluster as the $O$. vulgaris s. str. plus $O$. tetricus. These authors suggest treating this grouping as an $O$. vulgaris species group. These and other studies (such as the above cited and those of Strugnell et al. (2005) and Teske et al. (2007)) included only a limited number of specimens from the southern part of South America.

The Gould octopus, O. mimus, is an important target of fisheries along the southern Pacific coasts of South America, from central Chile to northern Peru (Rocha and Vega 2003, Cardoso et al. 2004). Octopuses from these locations were considered as synonymous with the cosmopolitan species $O$. vulgaris, but were recently recognized again as a separate species by Guerra $\mathrm{et} \mathrm{al}$. (1999) and by Söller et al. (2000), who found more than $12 \%$ of nucleotide divergence between the two species. However, these authors only studied three specimens from a single locality (Iquique, northern Chile), all showing the same haplotype. On the Atlantic coast of southern South America, the commercially exploited O. tehuelchus or "pulpito" is distributed from southern Brazil to approximately $44^{\circ} \mathrm{S}$ in Argentina (Iribarne 2009). To date, the phylogenetic relationships of this species with others of the genus Octopus remain unknown.

The aim of the present study was to assess the relationships among representatives of $O$. тітиs from localities not studied previously (the southeastern Pacific coast of Chile and Peru) and those previously sequenced, in order to estimate their phylogenetic relationships with other Octopus species, particularly $O$. vulgaris, and to assess the support for the monophyletic status of $O$. vulgaris through the use of Bayes factors. We also aimed to study the relationships of the poorly known species $O$. tehuelchus from the southwestern Atlantic Ocean (Argentina) with other species of the genus using the COIII gene.

\section{MATERIALS AND METHODS}

\section{Specimens}

Samples were obtained by artisanal fishing; the species O. minus was collected near Coloso (north-

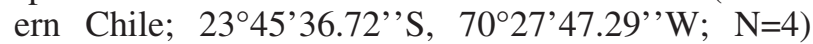
and Callao (Peru; 12 $2^{\circ} 04^{\prime} 21.27^{\prime \prime} S$ 7 $77^{\circ} 09^{\prime} 41.73^{\prime \prime} \mathrm{W}$; $\mathrm{N}=3$ ). Samples of $O$. tehuelchus were collected in the San Matías Gulf (Argentina; 40 47'11.08'S $64^{\circ} 53^{\prime} 45.52^{\prime \prime} \mathrm{W} ; \mathrm{N}=3$ ). Tissue samples were obtained from the arm of freshly caught specimens and stored in $90 \%$ ethanol at $-20^{\circ} \mathrm{C}$ until DNA extraction.

Sequences of COIII for two specimens of $O$. mimus from Chile and Costa Rica, for 16 O. vulgaris from different locations worldwide, and for 42 additional species from the subfamily Octopodinae were obtained from GenBank for comparison (Table 1). Some of 
TABLE 1. - Specimens, sampling regions, sample sizes and accession numbers of DNA sequences included in the phylogenetic inferences with COIII. Sequences reassigned to other genera by Norman and Hochberg (2005) that are still identified as Octopus in GenBank have their accession numbers underlined; specimens marked as "unplaced" are those of uncertain position but left in the genus until further revision by the same authors. Species used as outgroups are listed at the bottom of the table.

\begin{tabular}{|c|c|c|c|}
\hline Species & Sampling region & Sample size & Accession number \\
\hline Abdopus aculeatus (D’Orbigny, 1834) & Orpheus Island, Queensland, Australia & 1 & $\underline{\mathrm{AJ} 628213^{\mathrm{e}}}$ \\
\hline Ameloctopus litoralis Norman, 1992 & Dudley Point, Northern Territory, Australia & 1 & AJ628207e \\
\hline Amphioctopus exannulatus (Norman, 1993) & Lizard Island, Queensland, Australia & 1 & $\underline{\mathrm{AJ} 628223^{\mathrm{e}}}$ \\
\hline \multirow{2}{*}{ Amphioctopus kagoshimensis (Ortmann, 1888) } & One tree Island, Queensland, Australia & 1 & $\overline{\mathrm{AJ}} 628226^{\mathrm{e}}$ \\
\hline & Jogashima Island, Japan & 1 & ${\overline{\mathrm{AB}} 573193^{\mathrm{i}}}$ \\
\hline \multirow[t]{2}{*}{ Amphioctopus marginatus (Taki, 1964) } & Northern Sulawesi, Indonesia & 1 & $\mathrm{AJ} 628232^{\mathrm{e}}$ \\
\hline & Nha Trang, Vietnam & 1 & AB573196 \\
\hline Amphioctopus mototi (Norman, 1993) & New South Wales, Australia & 1 & AJ628233 ${ }^{\mathrm{e}}$ \\
\hline Amphioctopus ocellatus (Gray, 1849) & Tokyo, Japan & 1 & ${\overline{\mathrm{NC}} 007896^{\mathrm{f}}}^{\mathrm{N}}$ \\
\hline Amphioctopus ovulum (Sasaki, 1917) & East China Sea, Japan & 1 & ${\mathrm{AB} 573198^{\mathrm{i}}}^{\mathrm{A}}$ \\
\hline Callistoctopus alpheus (Norman, 1993) & One Tree Island, Queensland, Australia & 1 & $\mathrm{AJ}_{628215^{\mathrm{e}}}$ \\
\hline \multirow{2}{*}{ Callistoctopus aspilosomatis (Norman, 1993) } & One Tree Island, Queensland, Australia & 1 & AJ628216 $^{\mathrm{e}}$ \\
\hline & Miyagi Island, Okinawa, Japan & 1 & AB573205 \\
\hline Callistoctopus bunurong_(Stranks, 1990) & St. Leonards Pier, Victoria, Australia & 1 & AJ628219e \\
\hline Callistoctopus dierythraeus (Norman, 1993) & Magnetic Island, Queensland, Australia & 1 & $\overline{\mathrm{AJ} 628222^{\mathrm{e}}}$ \\
\hline Callistoctopus graptus (Norman, 1993) & Townsville, Queensland, Australia & 1 & AJ628224 \\
\hline Callistoctopus minor Sasaki, 1920 - UNPLACED & East China Sea, Japan & 1 & ${ }_{\mathrm{AB} 573201^{\mathrm{i}}}$ \\
\hline Callistoctopus luteus (Sasaki, 1929) & Kanagawa, Miura, Japan & 1 & AB573206 \\
\hline Cistopus indicus (Rapp, 1835) & Taichung Fish Market, Taiwan & 1 & AJ628208e \\
\hline Enteroctopus dofleini (Wulker, 1910) & British Columbia, Canada, Pacific Ocean & 1 & X83103a \\
\hline Grimpella thaumastocheir Robson, 1928 & Pt. Victoria Jetty, South Australia & 1 & AJ628209e \\
\hline Hapalochlaena fasciata (Hoyle, 1886) & Moreton Bay, Queensland, Australia & 1 & AJ628210 \\
\hline Hapalochlaena maculosa (Hoyle, 1883) & St. Leonards Pier, Victoria, Australia & 1 & AJ628212e \\
\hline Hapalochlaena sp. Norman, 2000 & Darwin, Australia & 1 & AJ628211 ${ }^{\mathrm{e}}$ \\
\hline Macroctopus maorum Hutton, 1880 & Potsea Pier, Victoria, Australia & 1 & AJ628231 ${ }^{\mathrm{e}}$ \\
\hline Octopus australis Hoyle, 1885 - UNPLACED & Port Stephens, New South Wales, Australia & 1 & AJ628217e \\
\hline $\begin{array}{l}\text { Octopus berrima Stranks and Norman, } 1993 \text { - } \\
\text { UNPLACED }\end{array}$ & Edithburg Jetty, South Australia & 1 & AJ628218 \\
\hline Octopus bimaculatus Verril, 1883 & California, USA, Pacific Ocean & 1 & $\mathrm{X} 83100^{\mathrm{a}}$ \\
\hline \multicolumn{4}{|c|}{$\begin{array}{l}\text { Octopus bimaculoides } \\
\quad \text { Pickford and McConnaughey, } 1949 \quad \text { Santa Barbara, CA, USA, Pacific Ocean }\end{array}$} \\
\hline Octopus californicus Berry, 1911 - UNPLACED & Ellwood, Santa Barbara Coast, CA, USA, Pacific Ocean & 1 & $\mathrm{AJ} 250483^{\mathrm{d}}$ \\
\hline $\begin{array}{l}\text { Octopus californicus Berry, } 1911 \text { - UNPLACED } \\
\text { Octopus cyanea Gray, } 1849\end{array}$ & Queensland, Australia & 2 & $\begin{array}{l}\text { X97955 } \\
\text { AJ628220 }\end{array}$ \\
\hline Octopus insularis Leite and Haimovici, 2008 & Recife, North Brazil, Atlantic Ocean & 2 & $\begin{array}{l}\text { AJ012123 } \\
\text { AJ012124c }\end{array}$ \\
\hline Octopus kaurna Stranks, 1990 - UNPLACED & Port Phillip Bay, Victoria, Australia & 1 & AJ628227 \\
\hline Octopus maya Voss and Solis, 1966 & Yucatán Peninsula, México & 1 & GU362546 ${ }^{\mathrm{i}}$ \\
\hline \multirow{5}{*}{ Octopus mimus Gould, 1852} & Iquique, North Chile, Pacific Ocean & 1 & AJ012128c \\
\hline & Coloso, North Chile, Pacific Ocean & 2 & $\begin{array}{l}\text { GU355928 } \\
\text { GU } 355929^{\mathrm{h}}\end{array}$ \\
\hline & Callao, Peru, Pacific Ocean & 2 & GU355927 ${ }^{\mathrm{h}}$ \\
\hline & & & GU355933 \\
\hline & Isla de Cocos, Costa Rica, Pacific Ocean & 1 & $\mathrm{AJ} 250480^{\mathrm{d}}$ \\
\hline Octopus ocellate sp.A Norman, 1998 & Victoria, Australia & 1 & AJ628234 \\
\hline Octopus oculifer Hoyle, 1904 & Galapagos Islands, Pacific Ocean & 1 & AJ628235 \\
\hline Octopus pallidus Hoyle, 1885 - UNPLACED & St. Leonards Pier, Victoria, Autralia & 1 & AJ628236 \\
\hline Octopus rubescens Berry, 1953 - UNPLACED & California, USA, Pacific Ocean & 1 & $\mathrm{X} 83101^{\mathrm{a}}$ \\
\hline Octopus salutii Verany, 1839 - UNPLACED & Banyuls, France, Mediterranean Sea & 1 & $\mathrm{AJ} 250484^{\mathrm{d}}$ \\
\hline Octopus tehuelchus D’Orbigny, 1834 & San Matías Gulf, Argentina, Southwestern Atlantic Ocean & 2 & $\begin{array}{l}\text { GU355937 h } \\
\text { GU355938 }\end{array}$ \\
\hline \multirow[t]{4}{*}{ Octopus tetricus Gould, 1852} & Wallaga Lakes, New South Wales, Autralia & 1 & $\mathrm{AJ} 628237^{\mathrm{e}}$ \\
\hline & Port Stephens New South Wales, Autralia & 1 & AJ628240e \\
\hline & Lucky Bay, Western Australia & 1 & AJ628238 \\
\hline & Fremantle Warf, Western Australia & 1 & AJ628239e \\
\hline \multirow[t]{12}{*}{ Octopus vulgaris Cuvier, 1797} & Banyuls, France, Mediterranean Sea & 1 & AJ012121 ${ }^{\mathrm{c}}$ \\
\hline & Lanzarote Is/Senegal, West Africa, Atlantic Ocean & 1 & $\mathrm{AJ} 250476^{\mathrm{d}}$ \\
\hline & Knysna Lagoon, South Africa, Indian Ocean & 1 & $\mathrm{AJ} 250487^{\mathrm{d}}$ \\
\hline & Tristan da Cunha, Atlantic Ocean & 1 & AJ $250477^{d}$ \\
\hline & Itajaí, South Brazil, Atlantic Ocean & 1 & AJ012122 \\
\hline & Rio de Janerio, Brazil, Atlantic Ocean & 1 & AJ616312d \\
\hline & Isla Margarita, Venezuela, Caribbean Sea & 1 & $\mathrm{AJ} 250478^{\mathrm{d}}$ \\
\hline & Seto Inland Sea, Japan & 1 & AJ616311d \\
\hline & North East Taiwan, Pacific Ocean & 1 & AJ $250479^{d}$ \\
\hline & Port Elizabeth, South Africa & 1 & AJ628241e \\
\hline & Costa Rica, Pacific Ocean & 1 & AJ012125 \\
\hline & Costa Rica, Caribbean Sea & 2 & AJ012126 \\
\hline
\end{tabular}


TABLE 1 (cont.). - Specimens, sampling regions, sample sizes and accession numbers of DNA sequences included in the phylogenetic inferences with COIII. Sequences reassigned to other genera by Norman and Hochberg (2005) that are still identified as Octopus in GenBank have their accession numbers underlined; specimens marked as "unplaced" are those of uncertain position but left in the genus until further revision by the same authors. Species used as outgroups are listed at the bottom of the table.

\begin{tabular}{|c|c|c|c|}
\hline Species & Sampling region & Sample size & Accession number \\
\hline Octopus vulgaris Cuvier, 1797 & Southern Indian Ocean & 3 & $\begin{array}{l}\text { FN424384g } \\
\text { FN424383g } \\
\text { FN424382 }\end{array}$ \\
\hline Octopus sp. & Port Elizabeth, South Africa & 1 & AJ628230 \\
\hline Octopus sp. & Isla del Coco, Costa Rica, Pacific Ocean & 1 & $\mathrm{AJ} 250481^{\mathrm{d}}$ \\
\hline Octopus sp. 5 Norman, 2000 & Coconut Wells, Western Australia & 1 & AJ628225 \\
\hline Octopus sp. 8 Norman, 2000 & Rockingham, Western Autralia & 1 & AJ628228 \\
\hline Octopus sp. 10 Norman, 2000 & Exmouth Gulf, Western Australia & 1 & AJ628229e \\
\hline Loligo vulgaris Lamarck, 1789 & & 1 & X97961 ${ }^{\mathrm{b}}$ \\
\hline Loligo forbesi Steenstrup, 1856 & & 1 & X97962 ${ }^{\mathrm{b}}$ \\
\hline Loligo reynaudii (D'Orbigny, 1839-1841) & & 1 & $\mathrm{X} 97960^{\mathrm{b}}$ \\
\hline
\end{tabular}

${ }^{\mathrm{a}}$ From Barriga Sosa et al. 1995; ${ }^{\mathrm{b}}$ From Bonnaud et al. 1997; ${ }^{\mathrm{c}}$ From Söller et al. 2000; ${ }^{\mathrm{d}}$ From Warnke et al. 2004; ${ }^{\mathrm{e}}$ From Guzik et al. 2005;

${ }^{\mathrm{f}}$ From Akasaki et al. 2006; ${ }^{\mathrm{g}}$ From Guerra et al. 2010; ${ }^{\mathrm{h}}$ This work; ${ }^{\mathrm{i}}$ Unpublished.

these species were placed in the genus Octopus at the time of the original publications, but were reassigned to other genera by Norman and Hochberg (2005). These species are in some cases still identified as Octopus in GenBank, in which case accession numbers are underlined in Table 1. The species Loligo forbesi, $L$. vulgaris and $L$. reynaudii were used as outgroups.

\section{Amplification and sequencing}

Total genomic DNA was obtained from tissues by phenol-chloroform extraction and ethanol precipitation (Maniatis et al. 1982). DNA was stored in double-distilled water at $-20^{\circ} \mathrm{C}$ until polymerase chain reaction (PCR) amplification. The mitochondrial COIII gene was amplified with the primers 5'-CATTTAGTTGATCCTAGGCCTTGACC-3' and 5'-CAAACCACATCTACAAAATGCCAATATC-3' (Ó'Foighil and Smith 1995). Amplifications were performed in 50- $\mu 1$ reaction volumes containing $15 \mathrm{ng}$ of genomic DNA, 1 unit Taq polymerase (Invitrogen, Brazil), $1 \times$ reaction buffer (10 mM Tris-HCl, pH 8.3, $50 \mathrm{mM} \mathrm{KCl}), 2.5 \mathrm{mM}$ $\mathrm{MgCl}_{2}, 25 \mathrm{nM}$ of each dNTP (dATP, dCTP, dGTP, dTTP), $3 \mu \mathrm{M}$ of each primer and double-distilled water to the final volume.

PCR conditions were as follows: 1 cycle of $2 \mathrm{~min}$ at $95^{\circ} \mathrm{C}, 30$ cycles of denaturation at $94^{\circ} \mathrm{C}$ for $30 \mathrm{~s}$, annealing at $48^{\circ} \mathrm{C}$ for $1 \mathrm{~min}$, and extension at $72^{\circ} \mathrm{C}$ for $1 \mathrm{~min}$; a post-treatment of $7 \mathrm{~min}$ at $72^{\circ} \mathrm{C}$ and a final cooling at $15^{\circ} \mathrm{C}$ were performed. PCR products were purified and sequenced at the facilities of Macrogen Inc. (Rockville, USA).

\section{Data analysis}

Sequences were inspected manually using the program CHROMAS version 2.23 (McCarthy 1998) and aligned using MUSCLE (Edgar 2004). All new sequences were submitted to GenBank; accession numbers are cited in Table 1. Phylogenetic relationships were assessed using the Bayesian approach implemented in MrBayes v3.1.2 (Ronquist and Huelsenbeck
2003). The model of sequence evolution that best fits our data set was chosen among 24 evolutionary models using MrModeltest 2.3 (Nylander 2004), considering both the complete data set and partitioning into the first, second, and third codon positions. The final model selected for the unpartitioned data set and for the first and third codon positions was GTR+I+G (Tavaré 1986). The selected model for the second codon position was GTR+G. The Bayesian analysis was conducted for the unpartitioned and codon position-partitioned data sets by running the Markov chain Monte Carlo with six chains for 3 million generations, on three independent runs. Trees were sampled every 100 generations and the first $25 \%$ of them were discarded as burn in. The robustness of clades was estimated by the Bayesian posterior probabilities (BPP). Results of the partitioned and unpartitioned analyses were compared by calculating Bayes factors (Nylander et al. 2004). The Bayes factor $\left(B_{10}\right)$ is defined as the ratio of the likelihood of the alternative model to the null model. We used the $\ln$ of the harmonic mean of the likelihood values sampled from the stationary phase of the MCMC run (obtained from MrBayes) as an estimator of the model likelihoods (Newton and Raftery 1994). The Bayes factor in favour of a model was then calculated as $2 \log _{\mathrm{e}} \mathrm{B}_{10}$ and the resulting values were interpreted following Kass and Raftery (1995), where values between 2 and 6 indicate positive evidence, between 6 and 10 strong evidence, and greater than 10 very strong evidence against the null model (and complementary, similar negative values, evidence favouring the null model). Additionally, we used Bayes factors to test the unconstrained tree topology versus trees obtained with MrBayes but forcing the monophyly of $O$. vulgaris, O. mimus, and $O$. vulgaris plus $O$. mimus.

\section{RESULTS}

The aligned sequences were 642 bp long. Four closely related haplotypes were found in O. mimus, differing by one or two mutations from each other. These new haplotypes differed by 2 to 4 substitutions from 
TABLE 2. - Bayes factor tests for alternative hypotheses of evolution in the genus Octopus. The Bayes factor was calculated as twice the natural logarithm of the harmonic mean of the likelihood values sampled from the stationary phase of the MCMC run $\left(2 \log _{\mathrm{e}} \mathrm{B}_{10}\right)$.

\begin{tabular}{|c|c|c|c|c|}
\hline \multicolumn{2}{|c|}{ Models compared } & \multicolumn{2}{|c|}{ Harmonic mean of $\ln \mathrm{L}$} & \multirow{2}{*}{$\begin{array}{l}\text { Bayes factor } \\
\text { (interpretation*) }\end{array}$} \\
\hline M0 & M1 & M0 & M1 & \\
\hline Unconstrained, non-partitioned tree & $\begin{array}{l}\text { Unconstrained tree, partitioned } \\
\text { by codon position }\end{array}$ & -9935.11 & -9772.63 & \multirow{4}{*}{$\begin{array}{c}324.96 \\
\text { (very strong evidence against M0) } \\
-6.6 \\
\text { (strong evidence against M1) } \\
-5.32 \\
\text { (positive evidence against M1) } \\
-4.58 \\
\text { (positive evidence against M1) }\end{array}$} \\
\hline $\begin{array}{l}\text { Unconstrained tree, partitioned } \\
\text { by codon position }\end{array}$ & $\begin{array}{l}\text { Monophyly of } O \text {. vulgaris enforced, } \\
\text { partitioned by codon position }\end{array}$ & -9772.63 & -9775.93 & \\
\hline $\begin{array}{l}\text { Unconstrained tree, partitioned } \\
\text { by codon position }\end{array}$ & $\begin{array}{l}\text { Monophyly of } O \text {. mimus enforced, } \\
\text { partitioned by codon position }\end{array}$ & -9772.63 & -9775.29 & \\
\hline $\begin{array}{l}\text { Unconstrained tree, partitioned } \\
\text { by codon position }\end{array}$ & $\begin{array}{l}\text { Monophyly of } O \text {. vulgaris and of } O \text {. mimus } \\
\text { enforced, partitioned by codon position }\end{array}$ & -9772.63 & -9774.92 & \\
\hline
\end{tabular}

* Kass and Raftery (1995)

that of Iquique published by Söller et al. (2000). Two haplotypes were found among the three $O$. tehuelchus sequenced, differing in two nucleotidic positions.

The value of the Bayes factor comparing the unconstrained, non-partitioned tree $\left(\mathrm{M}_{0}\right)$ versus the unconstrained, codon-partitioned tree $\left(\mathrm{M}_{1}\right)$ indicated very strong evidence against the null model (Table 2). Therefore, we present the topology obtained by considering different evolutionary models for each codon. Subsequent Bayesian analyses (that is, the testing of alternative topologies) were performed considering the codon-partitioned data set.

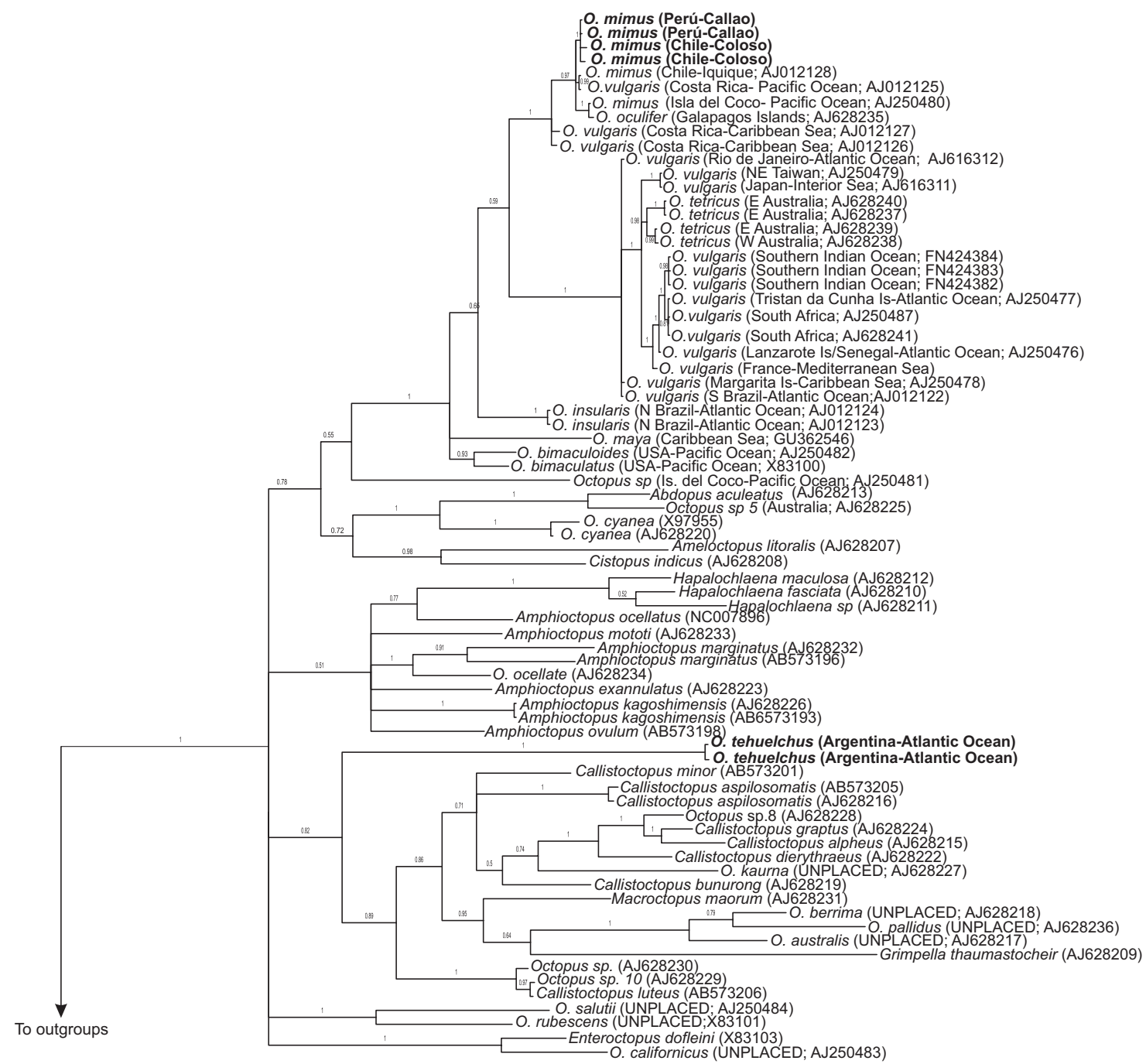

FIG. 1. - Phylogenetic relationships among species of the genus Octopus and other genera of the subfamily Octopodinae, estimated using COIII partial sequences and Bayesian inference, considering separate evolutionary models for each codon position. Loligo species (L. vulgaris, L. forbesi and L. reynaudii) were used as outgroups (not shown). Numbers on branches are the Bayesian posterior probabilities of the node to the right. Newly sequenced individuals are shown in bold. 
O. tehuelchus appears more closely related to the genera Callistoctopus, Grimpella and Macroctopus, as well as to "unplaced" Octopus species sensu Norman and Hochberg (2005), than to the clade containing most of the valid species of Octopus (Fig. 1). Our $O$. mimus specimens from Chile and Peru form a well supported clade with $O$. mimus from other localities: those from Isla del Coco (Costa Rica) and Iquique (Chile). However, this clade also includes an $O$. vulgaris specimen from the Pacific coast of Costa Rica and $O$. oculifer from the Galapagos Islands with a BPP of 0.97. The sister group of these "Pacific $O$. mimus" are the two O. vulgaris from the Caribbean Sea, also with high support. All remaining $O$. vulgaris from various geographic origins cluster in a group that also includes O. tetricus specimens from Australia $(\mathrm{BPP}=1)$. The specimens named $O$. vulgaris from Recife (northern Brazil) by Söller et al. (2000) and Warnke et al. (2004) and identified as a new species, $O$. insularis, by Leite et al. (2008) were placed as basal to this $O$. vulgaris/O. tetricus/O. mimus clade.

The results of the analyses conducted to evaluate alternative hypotheses of monophyly of $O$. vulgaris and $O$. mimus are summarized in Table 2. Bayes factors show strong evidence against the models in which the monophyly of $O$. vulgaris is enforced, and positive evidence against the monophyly of $O$. mimus and of $O$. vulgaris plus $O$. mimus.

\section{DISCUSSION}

In the last few years, studies on the molecular systematics of octopuses have helped to clarify their confusing systematics and phylogenetic relationships and also to identify and describe new species (Norman and Hochberg 2005, Allcock et al. 2007, Leite et al. 2008, Strugnell et al. 2009). In the present study, we focused on the genus Octopus using a Bayesian approach to estimate the phylogenetic relationships among published sequences of the COIII gene of Octopus species, of $O$. tehuelchus from the southwestern Atlantic Ocean (a species never included in phylogenetic analyses of the genus before), and of individuals of $O$. mimus from newly sampled localities in the Pacific Ocean (Chile and Peru).

The phylogenetic trees showed two major groupings: one included representatives of the genera Hapalochlaena, Grimpella, Amphioctopus and Callistoctopus and the "unplaced" Octopus species and the other included valid species of Octopus.

Species of the genus Callistoctopus and O. kaurna formed a well-supported clade, while the "unplaced" $O$. pallidus, O. berrima and $O$. australis were more closely related to the genera Grimpella and Macroctopus than to the valid species of Octopus. Specimens of O. tehuelchus (a valid species of Octopus according to Norman and Hochberg 2005) were included in this major cluster, as the sister group to Grimpella and Callistoctopus with high support. Therefore, the generic placement of this species may need a revision. The second main cluster included the majority of the valid species of Octopus sensu Norman and Hochberg (2005). Guzik et al. (2005) estimated the phylogenetic relationships among species of the genus Octopus using one nuclear and two mitochondrial genes, and demonstrated the polyphyly of the genus. However, several species included in the work of Guzik et al. were soon afterwards reassigned to other genera by Norman and Hochberg (2005). Nevertheless, the genus still appears to be polyphyletic because species of Ameloctopus, Abdopus and Cistopus are included in our phylogenetic tree within the Octopus cluster, although with medium support (BPP=0.78).

$O$. vulgaris specimens are included in two different, well-supported clades, with $O$. insularis as their sister group. These specimens were considered by Söller et al. (2000) and Warnke et al. (2004) as part of the $O$. vulgaris species complex, but Leite et al. (2008) described them morphologically, established their molecular distinctiveness and phylogenetic position using the 16S rRNA gene, and assigned them the name $O$. insularis. In the papers by Söller et al. (2000) these specimens group with other $O$. vulgaris forming a monophyletic clade, but they do not include other species of Octopus. In the present work, the position of these specimens in the phylogenetic tree, using COIII and including more species of the subfamily Octopodinae, remains the same as in Leite et al. (2008).

The topology of the tree obtained in this study using Bayesian Analysis was very similar to that of Guerra et al. (2010), in which specimens of $O$. vulgaris fall within two well-supported groups. One includes the $O$. vulgaris $\mathrm{s}$. str. and the other $O$. mimus, $O$. oculifer from the Galapagos Islands and $O$. vulgaris from Costa Rica (all eastern Pacific localities), with $O$. vulgaris from the Costa Rican Caribbean Sea in a basal position. Bayes factors showed that there is positive support for the topology in Figure 1 against that obtained by enforcing $O$. mimus monophyly, so there is a high probability that the $O$. vulgaris from Costa Rica and the $O$. oculifer specimens are in fact misidentified $O$. mimus. Regarding the Caribbean $O$. vulgaris, Jassoud (2010) sequenced the cytochrome oxidase subunit I gene of $92 \mathrm{O}$. vulgaris specimens from the Caribbean Sea (Curaçao, Dominica, Guadeloupe and Puerto Rico). He found $11 \%$ of sequence divergence between these specimens and $O$. vulgaris s. str. and suggest that they represent a distinct genetic lineage within the $O$. vulgaris species complex. In this study, Caribbean $O$. vulgaris appear as more related, and basal to, the $O$. mimus clade than to other $O$. vulgaris, a result very similar to that obtained by Söller et al. (2000), with the exception that they did not include $O$. oculifer in their study. Bayes factors showed that there is a strong support for the topology in Figure 1 against that obtained by enforcing $O$. vulgaris monophyly. Taken together, these results argue in favour of the presence of a cryptic species of Octopus in the Caribbean Sea different from O. vulgaris, O. insularis and O. maya (Fig. 1), and basal to 
O. mimus. As suggested by Söller et al. (2000), both "Caribbean $O$. vulgaris" and O. mimus could have originated from an ancestral species whose populations were separated by the rise of the Isthmus of Panama about 3 million years ago.

To resolve the incompletely described and wide geographic range of $O$. vulgaris, Warnke et al. (2004) estimated phylogenetic relationships among $O$. vulgaris from several localities, including South Africa, Tristan da Cunha (South Atlantic), West Africa, Japan, southern Brazil and the Caribbean, and compared the sequences of the COIII and $16 \mathrm{~S}$ genes with those of $O$. mimus specimens from Chile and the Pacific coast of Costa Rica. They confirmed a previous result by Söller et al. (2000) that $O$. mimus and $O$. vulgaris are separate lineages, and concluded that the monophyly of $O$. vulgaris was supported. However, they included a very limited number of other Octopus species. Guerra et al. (2010) estimated phylogenetic relationships among $O$. vulgaris specimens from worldwide locations and several other species of Octopus. These authors found that $O$. vulgaris from the Mediterranean Sea, eastern Atlantic, Pacific and Indian Oceans (O. vulgaris s. str.) clustered together with $O$. tetricus from Western Australia (a species not included in Warnke et al. 2004) with high bootstrap support, and proposed considering them as a monophyletic $O$. vulgaris species group. Bayes factors showed that there is strong support for the topology in Figure 1 against that obtained by enforcing $O$. vulgaris monophyly (that is, excluding $O$. mimus, $O$. tetricus and $O$. oculifer from the clade, and including the Costa Rican specimens), giving statistical support to the monophyly of an O. vulgaris s. str. + O. tetricus group sensu Guerra et al. (2010).

Our results emphasize the need for a revision of the generic status of $O$. tehuelchus, and more detailed population-level and/or phylogeographic studies in the $O$. mimus and $O$. vulgaris groups, in order to elucidate the number of species present, their limits and geographic ranges, and their phylogenetic relationships. This information will be useful for sustainable management of these important fisheries resources.

\section{ACKNOWLEDGEMENTS}

We are very grateful to the teams of the Unidad de Investigaciones de Invertebrados Marinos, Instituto del Mar (IMARPE) of Peru and of the Instituto de Investigaciones Oceánicas (Universidad de Antofagasta) of Chile for their assistance in field work, and to Lorena Storero for providing the $O$. tehuelchus samples. We also thank Juan José Martínez for his advice in data analysis. Financial and logistic support was provided by the Alfred Wegener Institute (Germany), and the Consejo Nacional de Investigaciones Científicas y Técnicas (CONICET, Argentina).

This work was carried out in the context of the $\mathrm{PhD}$ thesis of M.S. A.-J. at the Universidad Nacional de Córdoba, Argentina.

\section{REFERENCES}

Akasaki T., Nikaido M., Tsuchiya K., Segawa S., Hasegawa M., Okada N. 2006. Extensive mitochondrial gene arrangements in coleoid Cephalopoda and their phylogenetic implications. Mol. Phylogenet. Evol. 38: 648-658.

Allcock A., Strugnell J., Prodöhl P., Piatkowski U., Vecchione M. 2007. A new species of Pareledone (Cephalopoda: Octopodidae) from Antarctic Peninsula Waters. Polar Biol. 30: 883-893.

Barriga Sosa I.A., Beckenbach K., Hartwick B., Smith M.J. 1995. The molecular phylogeny of five eastern north Pacific Octopus species. Mol. Phylogenet. Evol. 4: 163-174.

Bonnaud L., Boucher-Rodoni R., Monnerot M. 1997. Phylogeny of cephalopods inferred from mitochondrial DNA sequences. Mol. Phylogenet. Evol. 7 (1): 44-54.

Cardoso F., Villegas P., Estrella C. 2004. Observaciones sobre la biología de Octopus mimus (Cephalopoda: Octopoda) en la costa peruana. Rev. Peru. Biol. 11: 45-50.

Carlini D.B., Young R.E., Vecchione M. 2001. A Molecular Phylogeny of the Octopoda (Mollusca: Cephalopoda) Evaluated in Light of Morphological Evidence. Mol. Phylogenet. Evol. 21 (3): 388-397.

Edgar R.C. 2004. MUSCLE: a multiple sequence alignment method with reduced time and space complexity. Bioinformatics 5: 113131. http://www.drive5.com/muscle.

Guerra A., Cortez T., Rocha F. 1999. Redescripción del pulpo de los changos, Octopus mimus Gould, 1835, del litoral chilenoperuano (Mollusca, Cephalopoda). Iberus 17(2): 37-57.

Guerra A., Roura A., González A.F., Pascual S., Cherel Y., PérezLosada M. 2010. Morphological and genetic evidence that $O c$ topus vulgaris (Couvier, 1797) inhabits Amsterdam and Saint Paul Islands (southern Indian Ocean). ICES J. Mar. Sci. 67: 1401-1407.

Guzik M.T., Norman M.D., Crozier R.H. 2005. Molecular phylogeny of the benthic shallow-water octopuses (Cephalopoda: Octopodinae). Mol. Phylogenet. Evol. 37:235-248.

Hochberg F.G., Nixon M., Toll R.B. 1992. Order Octopoda Leach, 1818. In: Sweeney M.J., Roper C.F.E., Mangold K.M., Clarke M.R., Boletzky S.V. (eds), "Larval" and Juvenile Cephalopods: A Manual for Their Identification. Smithsonian Contributions to Zoology 513, Smithsonian Institution Press, Washington, DC, pp. 213-280.

Iribarne O.O. 2009. Life history and distribution of the small southwestern Atlantic octopus, Octopus tehuelchus (d'Orbigny). J. Zool. 223: 459-565.

Jassoud, A.F.J. 2010. Genetic differentiation of eastern and western Atlantic Octopus vulgaris. MSc. thesis, University of Puerto Rico, 34 pp.

Kass R., Raftery A. 1995. Bayes factors and model uncertainty. JASA 90: 773-795.

Leite T.S., Haimovici M., Molina W., Warnke K. 2008. Morphological and genetic description of Octopus insularis, a new cryptic species in the Octopus vulgaris complex (Cephalopoda: Octopodidae) from the tropical Southwestern Atlantic. J. Molluscan Stud. 74: 63-74.

Maniatis T., Fritsh E.F., Sambrook J. 1982. Molecular cloning. A laboratory manual. Cold Spring Harbor Laboratory, Cold Spring Harbor, New York, 545 pp.

McCarthy C. 1998. Chromas ver. 1.45. School of Health Science, Griffith University, Queensland, Australia. http://www.technelysium com au/chromas html

Newton M.A., Raftery A.E. 1994. Approximate Bayesian inference by the weighted likelihood bootstrap (with discussion). J. R. Statist. Soc. B 56: 3-48.

Norman M.D., Hochberg F.G. 2005. The current state of Octopus taxonomy. Phuket Mar. Biol. Cent. Res. Bull. 66: 127-154.

Nylander J.A. 2004. MrModeltest. Program distributed by the author. Evolutionary Biology Centre, Uppsala University.

Nylander J.A., Ronquist F., Huelsenbeck J.P., Nieves-Aldrey J.L. 2004. Bayesian phylogenetic analysis of combined data. Syst. Biol. 53: 47-67.

Ó Foighil D.O., Smith M.J. 1995. Evolution of asexuality in the cosmopolitan marine Lasaea. Evolution 49: 140-150.

Robson G.C. 1929. A monograph of the Recent Cephalopoda. Part I, Octopodinae. Order of the Trustees of the British Museum, London, pp. 236. 
Rocha F., Vega M.A. 2003. Overview of cephalopod fisheries in Chilean waters. Fish. Res. 60: 151-159.

Ronquist F., Huelsenbeck J.P. 2003. MrBayes 3: Bayesian phylogenetic inference under mixed models. Bioinformatics 19: $1572-1574$

Roper C.F.E., Hochberg F.G. 1988. Behavior and systematics of cephalopods from Lizard Island, Australia, based on color and body patterns. Malacologia 29: 153-194.

Söller R., Warnke K., Saint-Paul U., Blohm D. 2000. Sequence divergence of mitochondrial DNA indicates cryptic biodiversity in Octopus vulgaris and supports the taxonomic distinctiveness of Octopus mimus (Cephalopoda: Octopodidae). Mar. Biol. 136: $29-35$.

Strugnell J., Norman M., Jackson J., Drummond A.J., Cooper A. 2005. Molecular phylogeny of coleoid cephalopods (Mollusca: Cephalopoda) using a multigene approach; the effect of data partitioning on resolving phylogenies in a Bayesian framework. Mol. Phylogenet. Evol. 37: 426-441.

Strugnell J., Voight J.R., Collins P.C., Allcock A.L. 2009. Molecular phylogenetic analysis of a known and a new hydrothermal vent octopod: their relationships with the genus Benthoctopus (Cephalopoda: Octopodidae). Zootaxa 2096: 442-459.

Tavaré S. 1986. Some probabilistic and statistical problems in the analysis of DNA sequences. Lec. Math. Life Sci. 17: 57-86.

Teske P.R., Oosthuizen A., Papadopoulos I., Baker N.P. 2007. Phylogeographic structure of Octopus vulgaris in South Africa revisited: identification of a second lineage near Durban harbour. Mar. Biol. 151: 2119-2122.

Voight J.R. 1994. Morphological variation in shallow-water octopuses (Mollusca, Cephalopoda). J. Zool. 232: 491-504.

Warnke K., Söller R., Blohm D., Saint-Paul U. 2004. A new look at geographic and phylogenetic relationships within the species group surrounding Octopus vulgaris (Mollusca, Cephalopoda): indications of very wide distribution from mitochondrial DNA sequences. J. Zool. Syst. Evol. Res. 42: 306-312.

Scient. ed.: A. Guerra.

Received February 22, 2011. October 24, 2011.

Published online February 3, 2012. 